\title{
"Bird cages and boiling pots for potential diseases": contested ecologies of urban 'Swiftlet farming' in George Town, Malaysia
}

\author{
Creighton Connolly ${ }^{1}$ \\ National University of Singapore, Singapore \\ University of Manchester. UK
}

\begin{abstract}
This article details the social construction of the 'swiftlet farming' industry in George Town, Malaysia. It argues that narratives of health and disease continually police which landscape practices are acceptable for the increasingly globalizing and image conscious city. 'Swiftlet farming' refers to the use of inner city shophouses and other commercial buildings for harvesting the edible nests of swiftlets (constructed from their saliva). Due to the high global demand and prices for birds' nests, the number of swiftlet farms have exploded in cities and towns across the country over the past decade, as entrepreneurs have been trying to cash in on the lucrative industry. The competing discourses and reactions to swiftlet farming in George Town, particularly in relation to its alleged potential for causing outbreaks of disease such as avian flu or dengue fever offer an apt entry point for studying this contested normative landscape. In doing so, I draw on recent writing on landscape and political ecology to analyze how swiftlet farm(er)s have been politicized by various stakeholders as (in)appropriate for the urban landscape. The article concludes by considering the significance of such an approach can help to make sense of the contradictions and uncertainties that abound in urban health controversies.
\end{abstract}

Key words: political ecology, health, disease, landscape, birds' nest, Malaysia

\section{Résumé}

Cet article détaille la construction sociale de l'industrie «de l'élevage de salanganes» 'à George Town, Malaisie. Elle fait valoir que les récits de la santé et de la maladie déterminent en permanence ce qui est acceptable pour le paysage urbain d'une plus globalisante et consciente de son image. «De l'élevage de salanganes» fait référence à l'utilisation de shophouses du centre-ville et d'autres bâtiments commerciaux pour la récolte des nids comestibles de salanganes (construit à partir de leur salive). En raison de la demande mondiale et des prix élevés pour les nids d'oiseaux, le nombre de fermes de salanganes ont explosé dans les villes et villages à travers le pays au cours de la dernière décennie, que les entrepreneurs ont tenté de tirer profit de l'industrie lucrative. Les discours et les réactions concurrentes de l'élevage de salanganes à George Town, en particulier par rapport à son présumé potentiel de causer des épidémies de maladies telles que la grippe aviaire ou la fièvre de la dengue, sont d'un intérêt pour cette étude d'un «paysage normatif contesté». Je l'utilise «l'écologie du paysage politique» pour analyser la façon dont les exploitations de salanganes et leurs propriétaires ont été politisé par différentes parties et prenantes (in)appropriée pour le paysage urbain. L'article conclut en considérant l'importance d'une telle approche peut aider à donner un sens aux contradictions et des incertitudes qui abondent dans les controverses de santé en milieu urbain.

Mots clés: écologie politique, la santé, la maladie, le paysage, le nid d'oiseaux, Malaisie

\footnotetext{
${ }^{1}$ Dr. Creighton Connolly, Postdoctoral Research Fellow, Asia Research Institute, National University of Singapore, AS8 Level 7, 10 Kent Ridge Cres., Singapore, 119260. Previous address: Geography, School of Environment and Development, Universitv of Manchester, UK. Email: aricpc@nus.edu.sg. The research for this paper was supported bv the People Programme (Marie Curie Actions) of the European Union's Seventh Framework Programme under REA agreement $\mathrm{N}^{\circ}$ 289374 - ENTITLE. Thanks to Panagiota Kotsila and Rebecca Duckett-Wilkinson for inspiring and informing the writing of this article; to James Evans, Roger Keil, Maria Kaika, Erik Swvngedouw, and an anonymous reviewer for helpful comments on a previous version; and to Simon Batterbury for editorial assistance. This is the second article in Creighton Connolly, Panagiota Kotsila, and Giacomo D'Alisa (eds.) 2017. "Tracing narratives and perceptions in the political ecology of health and disease", Special Section of the Journal of Political Ecology 24: 1-124.
} 


\section{Resumen}

Este artículo detalla la construcción social de la industria de la agricultura de salanganas en George Town, Malasia. Ello argumentado que las narrativas de la salud y la enfermedad continuamente policía que las prácticas del paisaje son aceptables para la ciudad cada vez más globalizada y consciente de la imagen. la agricultura de salanganas se refiere al uso de shophouses y otros edificios comerciales para cosechar los nidos de los swiftlets (construidos a partir de su saliva). Debido a la alta demanda global y los precios de los nidos de salanganas, el número de "granjas de salanganas” han explotado en las ciudades y pueblos de todo el país en la última década, como los empresarios han estado intentando de cobrar en la lucrativa industria. Los discursos y reacciones compitiendo en torno a la agricultura salanganas en la ciudad de George Town, particularmente en relación con su supuesto potencial de causar brotes de enfermedades como la gripe aviar o el dengue, son un buen punto de partida para estudiar este controvertido paisaje normativo. Me baso en escritos recientes en la literatura emergente de ecología política de paisajes para analizar cómo "granjas de salanganas" y el agricultores han sido politizadas por diversos tenedor de apuestas como (in)apropiado para el paisaje urbano. El artículo concluye considerando la importancia de tal enfoque puede ayudar a tener sentido a las contradicciones e incertidumbres que abundan en las controversias de salud urbana.

Palabras claves: ecología política, salud, enfermedad, paisaje, el nido salanganas, Malasia

\section{Introduction}

I think this is really unhealthy for all of us. As we know, birds do carry along with them certain type of viruses that could be fatal to human beings [sic](resident letter, The Star, 14 May 2003: np).

This can already be observed from the gradual transformation of our townships into bird cages and boiling pots for potential diseases (See, 2004: np).

The above quotations signal to some of the typical concerns that have emerged in the controversies over 'swiftlet farming' in Malaysian cities, and the industry's potential health implications. As the second quote, in particular, indicates, the concern is with the conversion of inner city shophouses and their potential to act as "a time bomb for a serious epidemic outbreak" (Ho, 2009: N49). Such comments also indicate that severe health impacts are a potential, though unproven, effect of the proliferation of swiftlet farms within inner city, residential areas. This threat has been mobilized as further justification to relocate swiftlet farms to rural, agricultural, or industrial areas. 'Swiftlet farming' is a colloquial term which refers to the cultivation system of edible birds' nests (EBNs) by preparing specially designed buildings for swiftlets to roost and nest. Edible-nest swiftlets (Aerodramus Fuciphagus) are a small species of bird, found only in Southeast Asia, which make edible nests entirely of their saliva. Birds' nests are a Chinese delicacy which are believed to have a number of medicinal, therapeutic and pharmaceutical qualities, and consequently fetch over US\$2,000 on the international market (Figure 1). I use 'swiftlet farming' in scare quotes, because it is unlike traditional captive breeding programs in that swiftlets are free to roam and forage for food outside, only returning at night to roost. Therefore, it is more comparable to apiculture, as swiftlets, like bees, cannot be fully domesticated.

Traditionally, nests were collected from caves by largely indigenous peoples across Southeast Asia, where swiftlets would traditionally roost. However, a relatively recent response to the increase in price and demand for birds nest since the 1990s has been the proliferation of swiftlet farming, in Indonesia, Malaysia, Thailand and Vietnam. This practice originated in East Java, Indonesia as early as the 1960s, primarily by chance, as swiftlets were found nesting inside old or abandoned buildings. Following the subsequent swiftlet farming 'boom' in Indonesia, the practice of actively farming swiftlets spread to Peninsular Malaysia, starting in Sitiawan around the early-mid 1990s, as a result of the surging demand in China and overseas Chinese communities. This took place in the wake of rapid urbanization in the country (see McGee 2002), but was soon followed by the Asian financial crisis of 1997-1998, which left many of the buildings constructed dur- 
ing the previous boom abandoned. In addition, the repeal of rent control in Malaysia in the year 1999 also assisted in the proliferation of swiftlet farming in Malaysia, as investors could offer residents several times what their property was previously worth.

Most swiftlet farmers prefer the use of inner-city heritage buildings, as opposed to purpose-build buildings in rural areas because they are not only much cooler but also devoid of potential predators which would be more prevalent in rural areas. As the industry has developed, swiftlet farms proliferated, transforming the skyline and ambiance of towns across Malaysia and Indonesia, which together source of around 80 per cent of the global nest supply (Thorburn 2014). In Malaysia alone there are an estimated 30,000 swift houses generating an annual income of US\$300 million. This makes the nation the world's second largest exporter of birds' nests, after Indonesia, which supplies $75 \%$ of the 3,750 ton global demand for birds nest every year (Henry 2005). Yet, less than half of the birds' nest produced in Malaysia are consumed domestically, with the majority being exported to China, Hong Kong and Singapore. China has always been the largest consumer of edible birds' nest in the world, now accounting for $70 \%$ of the world's total consumption, with much of this trade historically being conducted through the port of Hong Kong (Lim and Cranbrook 2002; Thorburn 2014).

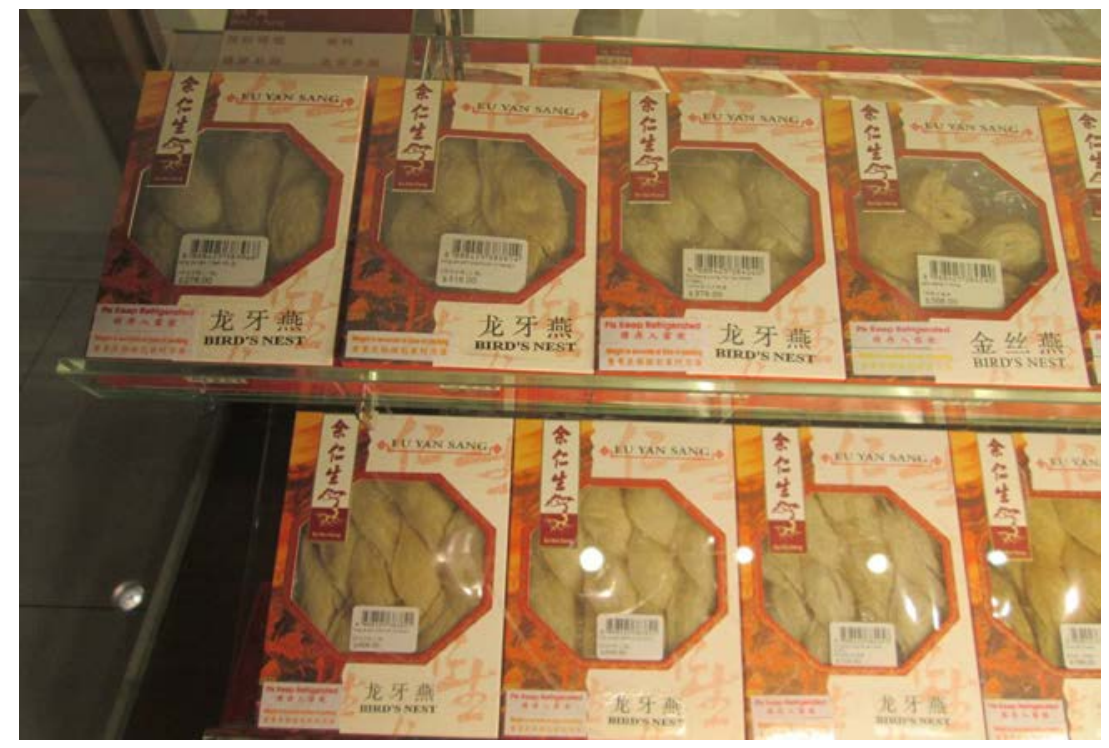

Figure 1: Birds' nests for sale at a Chinese Medicine Shop in Singapore's Chinatown. Prices range from \$278-800 Singapore dollars (US\$200-600).

According to research by the Small Medium Industries (SMI) Association of Penang, it was estimated that, as of 2007, 67\% of the swiftlet farming industry consisted of a 'self-build' group of self-taught farmers who personally establish their swiftlet farm(s), but that "...92\% of respondents in this group experienced failure in harvesting edible birds nests' from their farms" (Merican 2007: 6). This has accounted for much of the health and nuisance related controversies over swiftlet farms, as some of these farmers do not have formal training in their proper management. As Lim and Cranbrook stated, "most nest-farming ventures are undertaken by amateur entrepreneurs lured by the lucrative aspects of this industry. The expectation of instant profit gives a false sense of perception, yet is extremely seductive. This represents the core of all underlying problems associated with swiftlet houses in urban areas" (2002: 149). Furthermore, the informality of the trade, and lack of adequate government regulation of the industry has exacerbated these problems as there are only a series of 'guidelines' released by the Ministry of Agriculture to mitigate health and safety risks stem- 
ming from swiftlet farms. ${ }^{2}$ Moreover, given the industry's strong economic boost to the country, the Malaysian Government has occupied a rather contradictory position of promoting while also regulating the industry, which has contributed to a lack of firm action on proliferating swiftlet farms.

The primary question that I am concerned with in this article is how the perceived impact of swiftlets and swiftlet farms on human health and quality of life in Malaysian cities is framed by different stakeholders. In particular, I consider the ways in which what come to be regarded as legitimate knowledge about public health and disease are constructed and contested by different stakeholders. This article focuses on the UNESCO World Heritage City of George Town (Penang), which has experienced the most significant controversy over swiftlet farms in the city due to their perceived incompatibility with the UNESCO status (see Connolly, forthcoming). Swiftlet farms were thus declared illegal in the inner city area as of 2010, which resulted in the announcement of a three year 'grace period' for existing swiftlet farms to relocate elsewhere. ${ }^{3}$ Penang is a small state situated on the Strait of Malacca on the Northwest coast of Peninsular Malaysia, which consists of Penang Island and a sliver of adjacent land on Peninsular Malaysia (Figure 2). George Town, its capital city, is located on the northeastern most part of Penang Island, and has a highly diverse population base, given its history as a thriving entrepôt.

This article utilizes a landscape political ecology (LPE) approach, which, as the name suggests, brings together insights from landscape studies with those of urban political ecology (see Neumann 2011; Walker and Fortmann 2003). This approach is well suited for examining the political ecologies of health: as King (2010) has pointed out, political ecology and health geographies draw on ideas of place and landscape and utilize an understanding of place as a socially (re)constructed phenomenon. As such, my focus in this article is on the discursive practices and narratives circulating through my field sites, and how they have resulted in shaping the urban landscape. In doing so, I aim to demonstrate how urban political ecologies of health and disease can be enriched through a more detailed analysis of landscape and the discourses built into them. In doing so, I will empirically demonstrate how the 'moral geography' of swiftlet farming is also bound up with definitions of appropriate uses of, and interrelations with, the urban environment (see Matless 1998; Proctor 1998; Brown 2015).

I will now provide a brief review of the political ecology of health literature, and how I suggest the landscape lens can make a positive contribution to the field. This will be followed by a brief methodology section, before turning to the empirical material. I conclude the article with a discussion of how to act upon the perceived health risks associated with the swiftlet farming industry, given the lack of empirical certainty and the heavily contested nature of the claims that have been made.

\section{2. (Landscape) political ecologies of health}

The political ecology of health is a promising field of study which has its origins in the disease ecology tradition of health and medical geography. Disease ecology has aimed to show how the relations between human populations and the environment contribute to producing disease (May 1958; Mayer 1996). As Mayer (1996: 441) writes, disease ecology examines how "humanity, including culture, society and behavior; the physical world...biology, including vector and pathogen ecology, interact together in an evolving and interactive system, to produce foci of disease." However King (2010), among others, have challenged a lack of focus on economic and political processes, leading to the development of the political ecology of disease as a new approach in health geography.

\footnotetext{
2 This is problematic because guidelines are not legally binding in the same way as laws or ordinances (see Connolly 2016, ch. 8).

${ }^{3}$ During this time, the State Government conducted enforcement action to remove all swiftlet farms from the inner city, but faced considerable resistance from swiftlet farmers in doing so, and ultimately were not completely successful (see Connolly, 2016; forthcoming).
} 


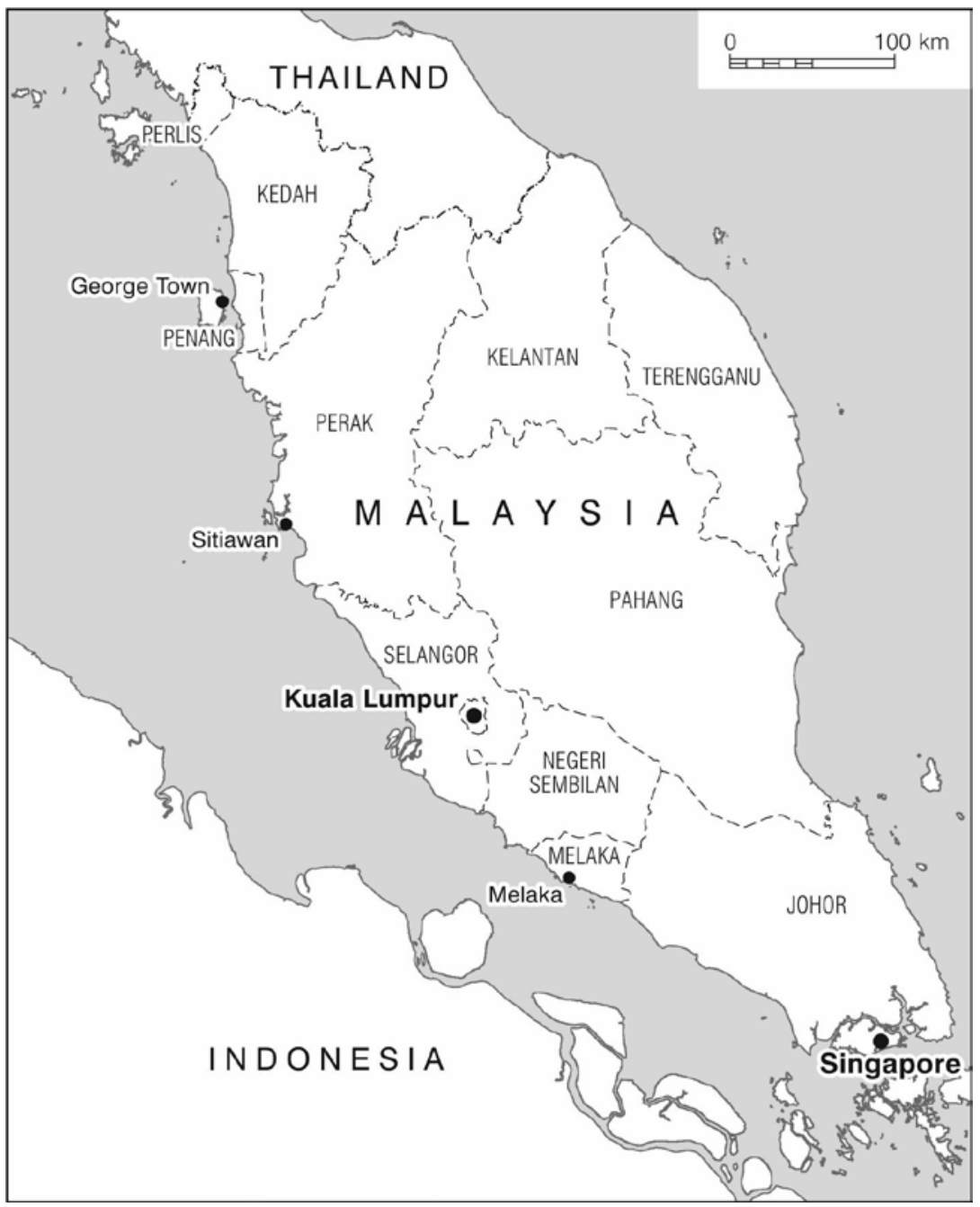

Figure 2: Map of Malaysia, noting Penang's location and those of other field sites visited. Map by Nick Scarle, Geography Cartography lab, University of Manchester.

The political ecology of disease has yet to receive adequate scholarly attention. As King (2010: 38) has recognized, "...health geography has provided less rigorous attention to the role of political economy in producing disease and shaping health decision-making" (emphasis added). Moreover, Mayer (1996) has suggested that political ecology's focus on the interaction between political interests, social institutions and human-environment interaction can bring about a greater systemic understanding of health and disease. Accordingly, a new wave of scholars are now beginning to recognize the usefulness of political ecology as a lens for studying issues of health and disease, particularly in urban areas (see Ali and Keil 2008; Braun 2008; King 2010; Mangiamelli 2013; Parizeau 2015). For instance, urban political ecology (UPE) can offer insights into the ways in which (urban) landscapes of health and disease are socially constructed, and not just 'naturally occurring' elements of urban life.

UPE examines the multitude of socio-natural flows into and out of the city: the urban metabolism. It is an extremely useful tool for understanding the relationships between urban environments and public health (Keil 2003; Swyngedouw 2006). Studies like these also include animals and other non-humans, and build on the work of Philo (1995), tracing the conflicts between animals and humans in the city by studying the particular discourses that circulate in certain communities, from rhetorics of health and disease to moral dis- 
courses, hostile or supportive of animal presence in the city. For instance, Thomson's study of flying foxes at Melbourne's Botanic Gardens (2010) demonstrated how authorities there deployed a series of accounts that portrayed the bodily characteristics of bats as threatening human bodies and spaces, which ultimately led to forced relocation of the bats. By exploring such discourses, it is then possible to draw out the spatial and political implications of conflicts over the use of urban space (Brown 2015).

Discourses of health and disease are also bound up with the 'moral landscapes' of particular places and regions, and can be politically motivated to achieve particular ends (e.g. Brown 2015; Notzke 2013; Proctor 1998; Thompson 2010). The concept of the moral landscape

...addresses the interrelationship between landscapes and moral values and judgments; it concerns how particular symbolic and material landscapes both shape and reflect notions of 'right/wrong', 'good/bad' 'appropriate/inappropriate' and 'natural/unnatural' in relation to particular people, practices, and things. ${ }^{4}$ It also concerns the ways in which certain moral boundaries are naturalized in, and through, landscapes, in the interplay of their material and representational forms and related significations (Setten and Brown 2009: 191).

The importance of the moral landscape is that it can lead to intense struggles over whose moral landscape will ultimately prevail, which in turn has significant consequences for how particular spaces are used (see Brown 2015; Matless 1998; Proctor 1998).

Furthermore, King (2010) has argued that research into the political ecology of health is also useful to interrogate how health discourses are produced by key actors and institutions, and to show how health is shaped through the relationship between social and environmental systems. Given this focus on discourse in political ecology of health studies, some scholars have now begun to focus on landscapes, given their constitution as 'discourse materialized' (see Mulligan et al. 2012; Schein 1997). A focus on landscape is important to examine the political ecology of health, since as Nash (2006: 8) has asserted "...without reference to specific landscapes is to assume at the outset that landscapes do not matter." Moreover, the concept of place has been used in previous health geography studies since the 1990s in order to study the critical intersections between health and social and cultural geography (Gesler 1992; Gesler and Kearns 2002). Indeed, political ecology and health geography both share an interest in places and landscapes, which makes the political ecology of health is a useful conceptual lens for this article.

\section{Methods}

To trace the shifting discourses and politics of swiftlet farming in Malaysia, multi-sited, ethnographic research was conducted for a total of six months from September 2013 to May 2014. In order to capture as wide a range of voices as possible, discourses were been examined in news articles (digital and print media), web blogs (and associated online comments), and in formal interviews and informal conversations with government officials, swiftlet farmers, heritage activists and city residents. Newspaper articles were collected from the major English dailies in Malaysia, namely The New Straits Times, The Sun, and The Star. At the peak of the birds' nest controversies these newspapers often contained one article on swiftlet farming per week. User comments on online news articles were also analyzed to get a wider sample of narratives.

Overall, I conducted over 40 formal and informal interviews and focus groups with 25 different stakeholders amongst four research sites. Many of these interviews utilized 'go along' or 'mobile' ethnographic methods which involves walking or driving with informants through the spaces in which they live and work on a daily basis (see Anderson 2004; Kusenbach 2003). In addition, I conducted a three month internship with the Penang Heritage Trust (PHT), a civil society organization based in George Town, which has been one of the primary actors involved in lobbying against swiftlet farming in the city. By working with the PHT,

\footnotetext{
${ }^{4}$ Moore (2006) has used the term, 'the urban normative', to refer to the institutions, policies and spatial practices that reinforce such meanings in the landscape of a particular place.
} 
I was put in daily contact with many of the key actors in the conflicts surrounding swiftlet farming in George Town, and I gained personal experience of engaging in negotiating with other stakeholders such as city and state government officials.

Despite my attempts to contextualize and balance the competing narratives and discourses that I encountered in this research, the following accounts feature a number of statements that may seem highly ambiguous, contradictory, or in some cases, entirely false. Not relying on quantitative 'facts' actually served as a way of entry into ethnographic fieldwork. Indeed, the elusiveness, rumors and stories that I encountered assumed a significant role in articulating 'symbolic discontent' with urban swiftlet farms and the enforcement actions employed to control them (Bunnell 1999: 14; Cook 2006; Tsing 2005). Kirsten Peterson's concept of 'phantom epistemologies' is particularly useful since it recognizes that realities and elusiveness exist in the same space (Peterson 2009). Similarly, Louise White argues that anecdotes, stories, and rumors need to be taken at "face value, as everyday descriptions or ordinary occurrences" (2000: 5). Nonetheless, they are all part of the story and help to illustrate how responses to urban swiftlet farming depend on the particular positionality and ideological beliefs of the different actors represented. At a broad level, discourses not only describe what makes stakeholders perceive swiftlet farming as (in)appropriate for particular spaces, but also illustrate normative ideals of how the business should be controlled and regulated.

\section{4 . 'In a fluff' over Swiftlet farms}

Like any reared animal, house-swifts are messy, smelly potential sources of infection transmissible to humans. Anyone who cares to visit the vicinity of a swift hotel can attest to the unhygienic conditions. In fact, I know of no owners who choose to stay nearby. (Tan 2007)

As this quotation suggests, health concerns have been one of the most frequently occurring reasons cited in newspapers, blogs, and personal interviews supporting the removal of swiftlet farms from urban areas. As Nash (2006: 9) puts, "...the material qualities of a specific landscape are critical to the production of certain diseases: local habitats that support anopheles mosquitoes, warm temperatures that allow the survival of parasites and bacteria, [and] the material and biological conditions of human communities." These conditions have all been linked to urban swiftlet farms in Malaysia, because of the insalubrious features of most swiftlet farms. In order to illustrate the interior condition of a typical swiftlet house, I take the following excerpt from my field notes: "The first thing that hit me was the stench, from the bird droppings layering the floor, as well as the lack of ventilation in the building. The only light coming in was from the entrance hole on the 'jack roof' at the far end of the building."

Furthermore, on the roofs of the buildings (typically not visible to most passersby) are often pools of stagnant water from which the swiftlets can drink (see Figure 3). Such pools are also typically placed on the interior of the buildings to keep the humidity levels up, or, alternatively, humidifiers are used. Yet, stagnant pools of water present an ideal environment for mosquito breeding, and have been targeted as potential sources of dengue. Lung diseases have been attributed to the effluent that is often emitted from buildings, including guano, mildew, mould and associated forms of bacteria. Moreover, the noise emitted from the buildings - and the birds inhabiting them - negatively affect mental health, it has been argued, and are seen as general sources of nuisance. These characteristics of swiftlet farms have accounted for much of the negative externalities and potential health impacts that I will explore in the following subsections.

I argue that swiftlet farming in Malaysia has, over the past twelve years, been embedded in an episode of 'acute collective anxiety' set off by perceived risks of dengue fever, avian flu, and other disease outbreaks that could be triggered by the activity in urban areas (Beardsworth 1990; Freidberg 2004). Much of this has to do with how swiftlet farming has been represented in the mass media, but also in outputs by activist groups, which have highlighted the dangers of swiftlet farming in urban areas. This fervor, however, has little to do with actual danger; as the links between such diseases and swiftlet farming often have little scientific backing. Rather, what alarms people is that the risks hidden within the (at one time) rapidly growing industry 
are neither well understood by science nor properly regulated by government. A fundamental friction has therefore arisen over the possible risks arising from the industry, and how they are to be determined.

This tension seems to stem back to the fact that the natural sciences have for some time been regarded as the legitimate and primary form of knowledge in many societies (Latour 1987). This has also had significant consequences for which understandings of disease - and their causes - become sanctioned as 'proper.' Many forms of boundary work are involved in the social struggles over which group has authority, and hence over which form of knowing is taken as legitimate. This is especially problematic given that the participants in these struggles portray their standpoints as legitimate in different ways. For instance, swiftlet farmers' associations have been able to command a great deal of political and economic power in Malaysia, and have exerted considerable influence in negotiating their right to urban space. Such industry associations have attained such a great deal of power not only through their strong political and economic position, but also through the discursive strategies that they have used in legitimizing swiftlet farming in George Town. On the other hand, members of civil society organizations (CSOs) such as the PHT utilized their quotidian experience of living amongst swiftlet farms as the basis for resistance to such dominant power relations.

Scholars like Dunn (2001) and Loftus (2012) have argued that everyday, local spaces are key sites for the symbolic contestation of unequal power relations. Their work aims to show how particular 'strategies and tactics' of everyday life are useful for considering the 'elements of creative resistance' to dominant power relations in society, employed by people such as city residents, urban activists, and even researchers (see de Certeau 1984). The approach in this article aims to extend this work, by considering how the socioenvironmental challenges posed by swiftlet farming in Malaysia are discursively framed and contested in an everyday, quotidian manner. I will discuss four specific areas of concern that have been raised in regards to the potential impacts of swiftlet farms on public health, which I will review in turn: avian flu, dengue fever, lung and respiratory disease and quality of life.

\section{Avian influenza}

Avian influenza, or bird flu, is a common enough condition for wild and domestic birds. Indeed, as Hinchliffe and Bingham point out, "the wide variety of subtypes of influenza virus provides a large reservoir of viruses that 'perpetually circulate' in bird populations" (2008: 218). The popularized spread of diseases between species barriers, such as the H5N1 strain, which crossed to humans in 1997 (in Hong Kong, with 18 cases) have caused considerable concern that the same could happen with swiftlets as well. As one Penang doctor cautioned in a newspaper editorial, "we should ask ourselves why these new diseases are cropping up more regularly than ever in the past decade. Is it because human populations are being brought closer to wildlife due to our own selfish needs to satiate our hunger for exotic animals and their products?" (See 2004). This editorial commended the economic benefits brought about by the swiftlet farming trade, but also cautioned about the 'unknown diseases' that the public could be exposed to as a result.

Similarly, an open letter written by Rebecca Duckett-Wilkinson - a former member of the PHT - to the Penang State Government on June 20, 2010, she cited a claim from the World Health Organization (WHO) that, "all birds are thought to be susceptible to infection with influenza viruses." ${ }^{5}$ She also cited a report indicating that "the avian flu virus could be introduced to swiftlets...from migratory waterfowl, which are thought to carry the H5N1 virus in its highly pathogenic form, sometimes over long distances." Duckett-Wilkinson went on to speculate that "living in such close proximity to one another, contaminated swiftlets would quickly transfer the disease between themselves, increasing the chances for human infection either via direct contact with contaminated birds or contaminated feces, the two most common sources of infection." These accounts recognize that swiftlets are not presently carriers of avian flu, but draws attention to the possibility that they could contract the disease if the proliferation of swiftlet farms is to continue unchecked.

\footnotetext{
${ }^{5}$ World Health Organization, "Avian Influenza "bird flu"

www.who.int/mediacentrefactsheets/avian_influenza/\#countries. February 2006.
} 


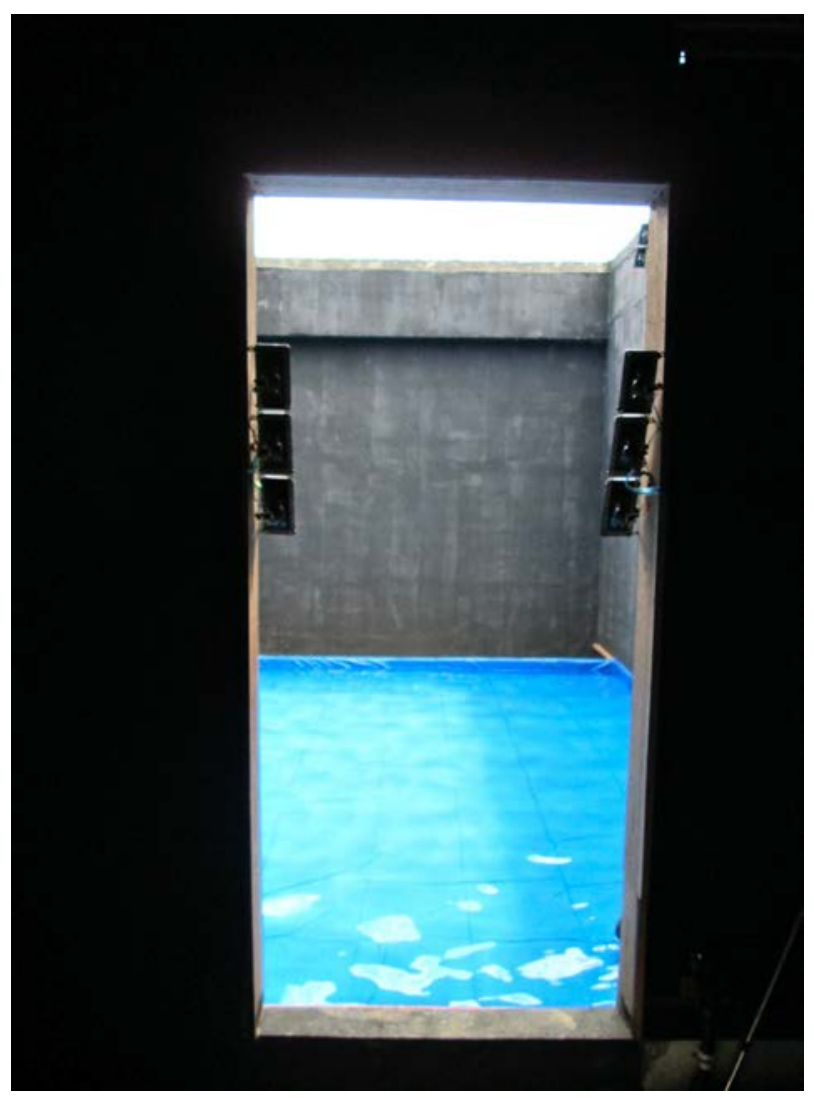

Figure 3: View from the inside of an under-construction swiftlet farm, showing the rooftop entrance and pool, typical for many urban swiftlet farms. Note also the speakers on the door, used to play recordings of swiftlet calls to attract the birds. Photo: author.

The mutability and adaptability of viruses, along with the intensity and density of animal-human cohabitation in Malaysian cities has accounted for considerable public concern. In response to a question about whether swiftlets could potentially spread avian flu, a PHT council member, Clement Liang, shared some of the same concerns as Duckett-Wilkinson, emphasizing the close proximity of the birds to humans, and the mutability of viruses between different species. In cementing this point, he asked rhetorically:

...do you really think that swiftlets can't possibly carry bird flu? They still share the same water and food sources of other birds, like dirty insects, and live in a human environment which is polluted with all sorts of things. Then you think about what the insects eat, the dirty leftover garbage and other things from the streets, the city is really an unclean environment. (Liang interview, Nov 13 2013)

This statement also contains a conflation of ideas about the dirt and impurities often associated with the urban environment, with ideas about the proper place of animals within cities. Such ideas can be seen to contain an implicit assumption that the removal of 'dirt' will naturally lead to a more ordered environment (see Cresswell 1992; Douglas 1970).

Given this possible risk, a George Town resident group also claimed in light of the 2013 bird flu outbreak in China: "...we think the people of Penang need to be warned about the possible risk. The Penang 
government is not clearing out the swiftlet houses in inner George Town. Are they waiting for an outbreak?" (The Star, 14 April 2013). In my interview with him, Liang also recalled a case earlier in 2013 where there was an alleged outbreak of the bird flu virus H5N1 in Vietnam that was blamed for the death of a five year old boy and nearly 5,000 swifts in Southern Vietnam (the Nation 2013). This raised concerns from the PHT who later announced in an open letter on April 15, 2013 that the event proves that swiftlets are indeed susceptible to H5N1. The event also seemingly disproved the former assumption that swiftlets were somehow immune to avian flu, as one prominent swiftlet farming expert once boasted "no health official anywhere in the world has ever found a single strain of avian flu virus amongst swiftlets" (Chin 2009).

Given the 104 recorded swiftlet houses in the George Town World Heritage Site at the time, the PHT argued that this event should serve as a warning to the State Government and Malaysian authorities to take the health threats posed by swifts seriously and renew their actions to eliminate swiftlet farms from residential areas. Yet, the PHT charged that the Malaysian authorities have been negligent regarding the potential health threats of swiftlet farms, as the deadly H7N9 strain of bird flu which also emerged in 2013 was being "ignored by authorities." However, there have not been enough scientific studies done which have gathered evidence in support of (or against) various claims regarding swiftlets' potential to contract and spread avian flu. Responding to an inquiry by Rebecca Duckett-Wilkinson on behalf of the PHT regarding this issue, the Malaysian Ministry of Health (MOH) stated that "the Department of Veterinary Services (JPV) and Department of Wildlife and National Parks (PERHILITAN)...confirmed no cases of avian influenza among poultry or migratory birds in Malaysia", and "swiftlet enterprises fall under the jurisdiction of the local authorities and JPV" (Malaysian Ministry of Health, letter, 24 April 2013).

Indeed, many online sources disputed the fact that the swiftlets in Vietnam died from bird flu and attributed numerous other reasons to the deaths: either that it was a case of poor animal husbandry which led to contamination in the swiftlet house; a farmer (unsuccessfully) trying to raise the birds in captivity; or even a case of sabotage between rival bird farmers (Craig Thorburn, personal communication, 23 May 2014). Previous research conducted by the Convention on International Trade in Endangered Species of Wild Fauna and Flora (CITES) conducted in 2005 determined that swiftlets are not carriers of the bird flu virus (Chuah et al. 2010). Most experts believe that both birds and humans can only contract avian flu through physical contact with other birds, particularly wild or domestic fowl, which are the primary carriers of the disease (see Hinchliffe and Bingham 2008). As the CITES report pointed out, there is no common interface between swiftlets and influenza vectors, since swiftlets do not share the same physical spaces as these other animals (see Chok and Bhatt 2006; Hinchliffe and Bingham 2008). Additionally, it noted that human outbreaks of the virus to date have been limited in number, and there have been few, if any, clear cases of human-human transmission, which suggests that the current H5N1 virus is poorly adapted to human hosts.

\section{Lung and respiratory disease}

A second health concern identified through this research is the 'extraordinarily high' incidence of lung disease amongst inner-city residents in the heritage zone, which Duckett-Wilkinson believes is directly correlated to the clustering of swiftlet farms (Duckett-Wilkinson, interview, 22 October 2013). The reason for this is that dried bird droppings have been known to harbor the yeast spore Cryptococcus, which forms colonies at $20-37^{\circ} \mathrm{C}$ (making Malaysia's tropical environment ideal) and is known to cause meningitis and lung infections in human beings through inhalation of the spores. ${ }^{6}$ Indeed, Duckett-Wilkinson has spoken to several local doctors in George Town about this issue who have verbally confirmed that cases of lung disease are 'disproportionate' in Georgetown (Duckett-Wilkinson, interview, 22 October 2013). This point reflects insights about how the environmental conditions in a particular place can influence the incidence of disease, and how uneven health landscapes can be produced. Noting concern about the prevalence of bird droppings in Malaysian cities, one resident in Sungai Petani, just north of Penang, noted that 'vehicles and shop com-

\footnotetext{
${ }^{6}$ Duckett-Wilkinson, open letter, 20 June 2010; citing DeWitt, M.L. 'Cryptococcus'

http://emedicine.medscape.com/article/215354-overview.
} 
pounds are littered with bird droppings daily and everyone feels a foreboding sense that a health catastrophe is about to happen' (The Star, 6 February 2004).

Yet, considerable debate emerged around the question of whether or not these were from swiftlets or other birds. For instance, Carole Loh, President of the Association of Swiftlet Nest Industries (ASNI), claimed that these 'are actually that of the pigeons, as swiftlets are very particular and only release their droppings in the house' (in PLGCF 2010: 14). Furthermore, Loh made the (possibly exaggerated) claim that, "5000 tests have been conducted over the course of 10 years, and JPV can confirm that no dangerous pathogens have ever been detected in swiftlet droppings", rather, she attested, "pigeons and crows are the culprits, producing acidic and pathogenic droppings" (ibid). Moreover, she argued that "swiftlets like clean premises" and, accordingly, "the [swiftlet] houses are cleaned weekly" (Tan 2010: M4). Such claims were encountered repeatedly during my fieldwork, yet they were also refuted by critics and by proponents of the industry. For instance, Duckett-Wilkinson challenged in a response to the Star article, "I do not see any of the houses around me being cleaned on a weekly basis and maybe [Loh] would like to explain the green slime oozing from the back of 21 China Street - a very large swiftlet house" (correspondence, 20 January 2010). Responding to Loh's claims about the droppings, she argued, "I can assure you that the swifts do defecate whilst they fly about and you can see their droppings, which I need to scrub off with disinfectant from all surfaces of my home. I can assure you also that I certainly do not have hundreds of pigeons defecating on my property everyday" (ibid). In a similar fashion, many other residents raised concerns about the effluent from swiftlet houses, which is often dumped into (largely uncovered) city drains, along the sides of streets. One respondent elaborated on this danger by noting that "bird hotels are well ventilated. Some have exhaust fans on rooftops. Dried bird droppings, dried skin and muck are disposed of through these fans. The naked eye may not be able to see these fine airborne particles. Those living nearby breathe and eat this muck. These particles are also virus carriers" (New Straits Times, 9 September 2009). Such conditions clearly have broader health implications, such as the potential for lung infections or other bacteria-related diseases. Yet, as Braun (2008: 251) has argued, such "absent actors" have been by and large banished from many official understandings of urban health, even as they actively shape it. These deleterious aspects of the swiftlet farming industry was even acknowledged by the Malaysia Bird's Nest Association President, who cautioned that "some members have no experience in the industry and their operations might cause pollution that would harm the environment and health of residents living near their farms" (in Nathan 2003: 13). Yet, local governments and health authorities in Malaysia have not taken these personal accounts of urban health seriously, which has resulted in the proliferation of such unhealthy urban environments.

A further health hazard are swiftlet farms which operate on the upper story of another business, such as restaurants, cafes, and even hotels (see Figure 4). This is something that many stakeholders expressed concerns about, including Chow Kon Yeow, who pointed out that many customers of these buildings are not even aware of the swiftlet premise above. As he argued, "this is totally unacceptable I think...if you put a sign at the top, that says the top is a swiftlet farm, then the customer can choose to go, knowing full well, but deceiving people is not ethical" (interview, 22 October 2013). Nonetheless, such business patterns are not uncommon in George Town, and there were two restaurants in George Town's UNESCO zone which had very active swiftlet farms operating on the upper levels during the time of my fieldwork. Furthermore, there was also a hotel in Taiping, Perak, which operated a swiftlet farm on the top story, while the bottom three stories were rented out to human occupants! The health danger of such premises was made clear by DuckettWilkinson, who cautioned that the businesses underneath can potentially bring in dangerous fungus spores released from the feces through their air conditioning systems.

However, the 2007 Malaysian Swiftlet Farming Industry Report claimed that studies criticizing the cleanliness of swiftlet farmers focus on "errant swiftlet farmers" and are inspired by "jealousy and envy of the potential financial returns that such farms may bring" (Merican, 2007). This perception was shared by a swiftlet farmer that I met in Kota Kinabalu, who emphasized that it is in the best interest of swiftlet farmers to maintain clean premises. 


\section{Dengue fever}

Dengue fever is a tropical, mosquito borne disease that is strongly associated with urbanization (Dickin et al. 2014; Mulligan et al. 2012). Cities provide ideal habitats for the Aedes Aegypti mosquito, its primary vector, which depends on anthropogenic water sources for breeding (ibid). There are three types of dengue fever in humans, including dengue fever and its more severe forms of dengue hemorrhagic fever, and dengue shock syndrome. There is currently no vaccine or cure for the disease, which means that the primary method for controlling it is the reduction of breeding sites for Aedes mosquitoes. According to numerous sources, one of the primary causes of dengue is rapid urbanization combined with poor or non-existent urban planning (Dickin et al. 2014; Mulligan et al. 2012; Shankar 2014).

As Duckett-Wilkinson and her family have been personally affected by the industry over the years, she has been quite active in trying to lobby against the (at the time) pervasive swiftlet farms in George Town. As she explained, "this has not been a mindless campaign on my part but has been from a sense of frustration at the lack of recourse to law when it comes to my right as a citizen to have basic health and safety, no fear of disease and no noise pollution etc." (letter to UNESCO, May 5 2011). As a result of this experience, Duckett believes that there is a direct link between swiftlet farming and dengue fever, as explained in the following statement:

Just on China Street [her street] we had 5 cases of dengue but in the small area from China Street. Stewart Lane, Love Lane and Muntri Street, which, according to 2005 figures, have 23 swiftlet houses, there were too many cases of dengue. I personally know and work with 5 of the people who contracted dengue just in this area. There has just been more dengue on our street. This is appalling! Studies have to be done to see if there is a correlation between dengue cases and location of swiftlet farms. (Duckett, letter, May 5, 2011)

However, there has been no research done to link cases of dengue to the location of swiftlet farms, despite repeated attempts to get this information from the State Health Department, who seemed unwilling to divulge figures. Therefore, in the absence of official evidence to support or deny the relationship between swiftlet farming and dengue fever, many swiftlet farmers continue to debunk these concerns by arguing that, "a wellrun swift farm has no mosquitoes, as swiftlets consume insects" (Chin 2009); "Swiftlet house owners are often advised to use salt or ABATE (insecticide) to kill all insect larvae in their ponds", or even that such ponds "have been replaced by humidifiers, which do not allow the breeding of Aedes mosquitoes" (NSHiGT 2010; Oh 2009). Furthermore, one Penangite argued in a letter to The Star, "Dengue fever has been around for a while and during that time, the swiftlet industry was not at this magnitude. So why blame it on the swiftlet industry?" (Oh 2009). Indeed, dengue is also endemic in neighboring Singapore, where there are no swiftlet farms, so it cannot be tied solely to swiftlet farming.

The question of whether or not swiftlets are in fact a way of controlling dengue has been much debated, as indicated in the foregoing paragraph. For instance, Lord Cranbrook, a renowned swiftlet ecologist has demonstrated that their preferred foods include winged termites, flying ants, small hymenopterans including parasitic wasps, and flies. These are found mainly over forest and agriculture (Cranbrook 2010). Similarly, Duckett-Wilkinson has argued that "stagnant pools of water do cause mosquitoes but the birds obviously do not eat these even though there is a misconception that they keep areas mosquito free. The swiftlets are aerial and fly out to agricultural or forested areas to feed during the day" (Duckett-Wilkinson comment on NSFiGT 2010). Likewise, Liang also expressed doubt in my interview with him that mosquitoes constitute the main diet of swiftlets, "simply because they're so small...they would have to eat thousands of them to sustain themselves" (Liang, interview, 12 November, 2009). Their diet has also been studied by several swiftlet farmers who have been interested in the possibility of farming swiftlets in a more traditional (captive) manner, but have not found mosquitoes in their diets (Pak, interview, 1 October 2013). 


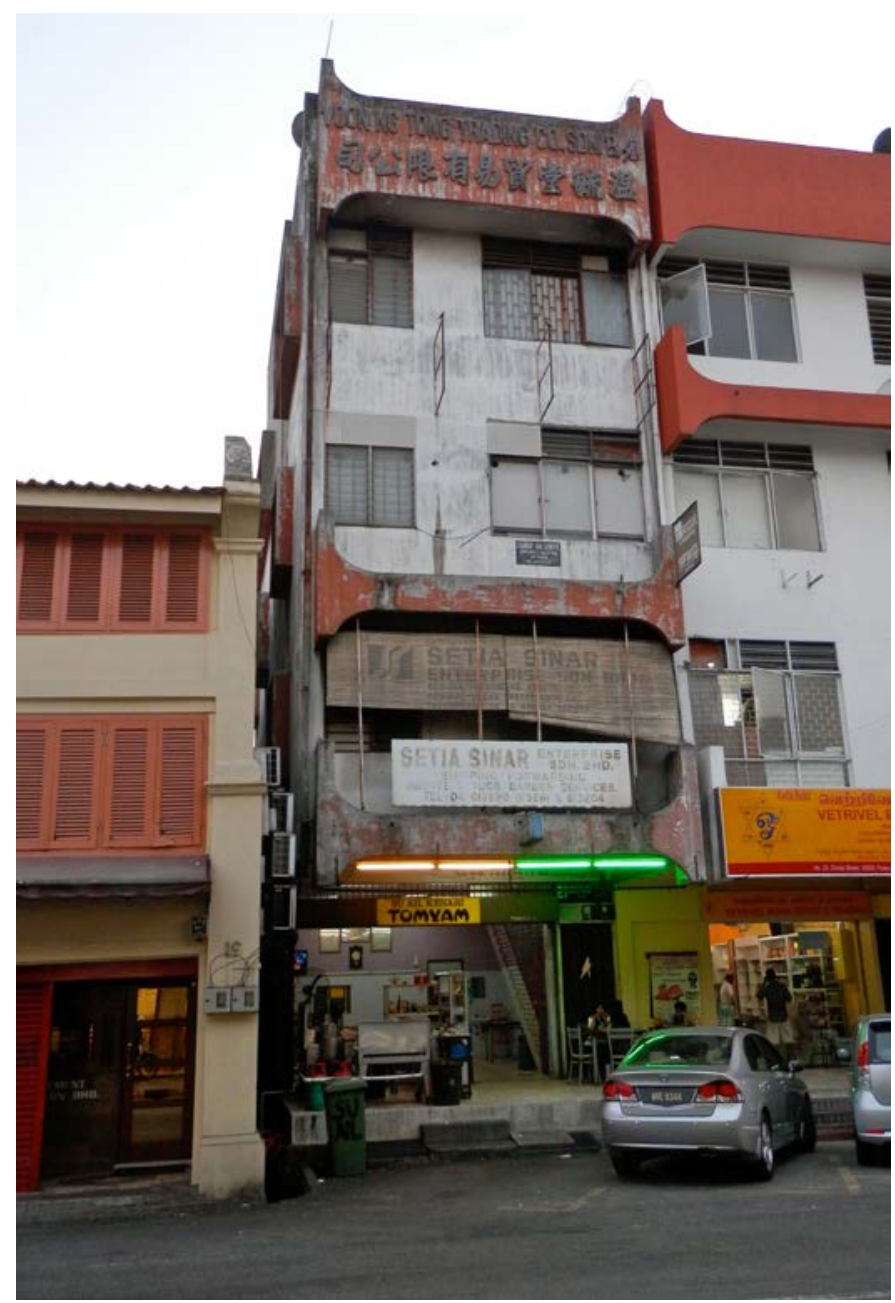

Figure 4: An active swiftlet farm above a popular noodle shop in central George Town, Penang 2014. Photo: author.

It is true that some operators do take steps to control the prevalence of mosquitoes in their farms, including the use of ABATE in their ponds, or using humidifiers as opposed to pools of water, as I have witnessed during my fieldwork. Moreover, there is even some debate amongst swiftlet farmers about the necessity of using pools inside the buildings. Some swiftlet farmers argue that the construction of pools is obsolete, noting that they can be replaced by humidifiers and other appliances in the interests of hygiene (Lim Chan Koon interview, 7 November 2013). Yet, renowned swiftlet farming consultant Harry Pak told me in an interview that pools are important for insect generation and even advocates for a 'wet-floor' system (but, see Lim 2008). In his view, pools are better than humidifiers because the latter can cause the growth of fungus on nests, since they push the air upwards inside a birdhouse instead of allowing evaporation of moisture from the floor (interview, 9 November, 2013).

Therefore, there is a clear dilemma between the (perceived) need for insect generation inside swiftlet farms - to provide food for the birds - and, on the other hand, the potential health threats created by potential mosquito breeding areas within urban areas. Such divergent perspectives speak to the proliferation of uncertainties with regards to 'proper' swiftlet farming methods, and their impacts on human health and wellbeing. This speaks to the need for more scientific research on the industry, and also proper regulation of farms. Swiftlet farmers' associations have attempted to ensure the cleanliness of their members' swiftlet farms, but 
their members typically only represent less than half of all swiftlet farmers in a given area (Ding T.H., Interview, 11 November 2013). Proper regulation of the industry is thus clearly needed to control such matters, but has been extremely patchy and largely ineffective throughout the country, as I have shown elsewhere (Connolly 2016).

\section{Intangible forms of disease}

Many of the externalities posed by swiftlet farming discussed in the previous sections do not only have a detrimental impact on human health, but also on the general quality of life and mental health. This section focuses more on those aspects of swiftlet farming which do not directly impact human health or cause tangible forms of disease. It is important to note that these should not be viewed as merely NIMBY ('not in my backyard') or nuisance complaints, but have in fact been linked by some individuals to increased stress levels or other impacts on mental health and well-being, which often are not accounted for in standard definitions of health and, particularly, disease. This sub-section discusses the sensory impact of swiftlet farming on urban residents, and the perceived impacts upon quality of life in the city.

For many people, the presence of swiftlets may go unnoticed, depending on their place of residence or work. However, for most people living or working in the vicinity of a swiftlet farm, the presence of large numbers of swiftlets living in close proximity to humans was 'offensive to the senses.' This resonates with Philo's (1995) study of slaughterhouses in Anglo-American cities, in which he described how the "dreadful smells and sounds" intrinsic to slaughterhouses, in part, resulted in their ultimate removal from the city.

According to Lim Chan Koon, the number one complaint from people (excluding in Penang and Melacca) regarding swiftlet farms is noise, which is actually more prevalent than health concerns. As one resident put it "Having the swifts for neighbors is like living in hell. No human being should be forced to live this way. I can't remember the last time I was able to open my windows for some fresh air. I just can't take this anymore." (Resident, Kuala Terengganu, quoted in Muhammad 2007). This was a common experience of critics of the industry, who did not open their windows for fear that swiftlets would fly in. Moreover, as Rebecca Duckett-Wilkinson wrote in a letter to UNESCO "On a daily basis we have to put up with these flying over us and their droppings all over our walls, courtyards and out door furniture. The noise of the birds is appalling, while they are flying around at daybreak and sunset, and is a constant nuisance at night" (Duckett-Wilkinson letter to UNESCO, May 5, 2011).

However, such noise complaints do not only refer to the noise of the birds themselves, but also to the recordings that many operators used to attract the birds to their premises. These broadcast swiftlet calls on specially designed sound systems, and were played in the morning and the evenings, which are the most active times for the birds (see Figure 3). As one city resident complained: "All over these breeding places, noisy recorders are installed to lure the swallows from early dawn till the night. We are, in fact, living with the swallows" (in The Star, 3 March 2005: np). Another George Town resident explained that: "this has severely affected our quality of life. On weekends, when we look forward to just relaxing at home, we have to put up with the aural assault" (Lee 2010).

Commenting on public complaints that swiftlet houses were causing noise pollution, one Perak State Government official noted that "this industry is big but it is noisy", and conceded that "breeders should at least reduce the volume of the recordings" (The Star, 3 Aug, 2005). As one George Town resident agreed: "The sound systems used to attract swiftlets by playing amplified birdsong continuously constitutes noise pollution, which is a nuisance for residents of and visitors to George Town." However, since such recordings have been banned in George Town since 2012, she notes,

....in recent months, the main source of noise pollution is the birds themselves because numbers have soared and are now out of control. The sky above residences in George Town are full of birds emitting piercing sounds especially in the early hours of morning, late afternoon and evening. (Duckett-Wilkinson, open letter, June 20 2010) 
One question which could arise is whether such noise pollution is actually linked to mental health and quality of life, or if it is just a nuisance. One George Town resident argued for the former in a 2010 letter to The Star stating that, "research has shown that prolonged and continuous exposure to unwanted noise can have a detrimental effect on one's stress levels and mental health" (Lee 2010). This letter was written in response to an article two days prior, announcing plans by ASNI to sue the State Government over the planned eviction of swiftlet farms from the inner city. The resident in turn responded "what about the suffering neighbours? Can we sue the swiftlet farm owners for creating a public nuisance?" Similarly, one blogger on the site noswiftlethousesingeorgetown.blogspot.com likened living near swiftlet houses to "mental torture of daily shrieking."

However, as noted in the previous section, associations have attempted to vindicate the industry by blaming the complaints on the actions of just a few errant swiftlet farmers. As stated in the 2007 Malaysian Swiftlet Farming Industry Report (Merican 2007):

...almost all the publicity has been negative with the media [selectively] focusing their reporting on errant swiftlet farmers who do not adhere to the Guidelines set by the $<\mathrm{MOH}>$ but continue to carry on their swiftlet farming businesses in residential areas, vocalizing swiftlet chirps at over and above the permitted levels as well as not in accordance with the permitted timetable as set out by the Ministry, causing public health disturbances, renovating and constructing their swiftlet farms without the consent of the relevant councils". ${ }^{7}$

Moreover, pro-swiftlet farming lobbyists sought to put the noise issue into context, as one argued: "I would rather listen to the chirping of the birds than the deafening music from some shops and the roaring traffic" (quoted in The Star, 7 May 2010).

Regardless of the counter-narratives employed on behalf of swiftlet farmers, it is clear that a fundamental issue underlying each area of concern presented here (avian flu, dengue, cryptococcus and mental health) stems from the potential risks and dangers associated with the rearing of swiftlets in close proximity to dense human populations. Yet, as with avian flu and dengue fever, it is important to note that many residents were genuinely concerned about the pathological and moral consequences of swiftlet farming in the city, because of the incidence of disease experienced by them and their neighbors. Swiftlet farming can thus be considered what Beck referred to in Risk society as a 'modern' risk which cannot be easily detected or assessed, and therefore cannot be managed in the same way as more tangible risks (Beck 1992). The next section will briefly report on how various stakeholders sought to address this issue, given the lack of evidence available to dis/prove the various health risks surrounding urban swiftlet farms.

\section{Discussion: 'matters of fact', versus 'matters of concern'}

Place, Massey (2005) has argued, is always negotiated, fraught with antagonism and shaped through competing ideologies. If that is the case, she asks, what forms of dialogue may ensue in negotiating these different interests? This statement raises the question as to how the swiftlet farming issue can be resolved, particularly given the highly controversial nature of the industry. As Duckett-Wilkinson asserted, because the swiftlet farmers' associations (like ASNI) are so strong, NGOs like the Malaysian Nature Society, PHT, and SAM "really need to come together to take on the issue, and make more noise against [illegal swiftlet farming]. Otherwise [the PHT] will be no match for ASNI and others on their own" (interview, 12 November 2013). As she put it, the swiftlet associations are powerful, and more public awareness needs to be raised about the issue to counter ASNI's "manipulation" of the public opinion (ibid).

Consequently, most respondents sought to place responsibility on the state to regulate the urban environment, and protect the health of its citizens. As one resident complained "I always wonder why the Town Council is not taking any action...have we no other choice but to share our homes with these [birds]". This

\footnotetext{
7 These views are ratified in the 'Report on the Malaysia Swiftlet Nest Industry Issues' (Lim 2008) on behalf of the Malaysia Bird's Nest House Owners Association. They attribute the 'problem' swift houses to poor design and ignorant owners.
} 
lack of action has caused a considerable amount of anxiety, which as Mulligan et al (2012) have pointed out, can turn in to public distrust of government because of the lack of protection from risk and acknowledgement of uncertainty. This has certainly been the case in Penang, as residents feel that that State Government has not acted quickly or responsibly enough in the wake of such risks and uncertainties. Yet, as I have shown elsewhere, since these concerns were not quantifiable, they were not acted upon by the relevant health authorities, nor were they seen as grounds for removing swiftlet farms from George Town. ${ }^{8}$ Moreover, the Government's inaction was affected by a conflict of interest, whereby the lucrative nature of the swiftlet farming industry meant that some government officials were actually profiting from the industry's continued growth (Connolly 2016).

Some stakeholders suggested that many of the problems associated with swiftlet farms could be avoided in the first place through the support of swiftlet farmers' associations. In fact, the president of the Malaysian Bird's Nest Merchants Association (MBNMA), Lim Theam Siew, argued that they should be allowed to regulate the industry, since they oversee a large number of swiftlet farmers as their members. As he put it, "we have the experience and can educate operators on the proper way to set up and maintain 'birdhouses'. We teach them how to keep their premises clean and to ensure the nests are collected only when the chicks leave" (in Chok and Bhatt 2006: 7). However, it has been pointed out by various stakeholders that merchants' associations, such as the MBNMA, do not have much control over their members, and also that their members only represent less than half of all swiftlet farmers in a given area. This was acknowledged by Carole Loh in response to complaints against ASNI, and insisted that they were only able to control their members, and could not be held responsible for non-members (Cardosa interview, 8 October 2013).

Though it was never implemented, one suggestion that emerged out of these discussions was for the state to create "a hefty annual tax to be paid by each individual urban swiftlet farm until they have moved from the urban areas of George Town" (Duckett-Wilkinson, open letter, 20 June 2010). This tax would create a fund for emergency measures which could then be used in the case that there is an outbreak of one of the diseases discussed above, or for environmental disaster cleanup. As she further argued this tax payment also puts responsibility on swiftlet farmers for "the maintenance of their farms' health and safety measures and further reinforces their belief that swiftlet farming in urban areas amongst a dense population, poses no dangers to humans" (ibid). Moreover, it would seem to be within swiftlet farmers' own interests to encourage and co-operate with such regulatory measures because it would offset impacts to the surrounding community and allow them to continue their business in urban areas. Such strategies for mitigating potential sources of disease were also highlighted by Mangiameli, who underscored the role of moral judgements about those who were allegedly responsible for sources of toxic 'contamination' in Sicily, and those who were supposed to prevent potential health outbreaks (Mangiameli 2013; see also D'Alisa, this issue).

Finally, there is the question of how to proceed in the face of insufficient evidence to support or deny the health threats that have been made. Much of the evidence presented by government to downplay health risks is based on reports conducted by the federal Veterinary Department (JPV) or Perhilitan, which are official supporters and promoters of the industry. Similarly, comments made about the cleanliness of swiftlets and swiftlet farms mostly come from industry representatives and operators, which further implies bias. Yet on the other hand, many complaints about the industry have come from those who have alternative visions for the types of economic activities that George Town should promote. Therefore, what is needed is an impartial body that can arbitrate in the face of such disagreements. Or, in Latourian terminology, a representative spokesperson in a parliament of things that would adjudicate between 'matters of concern' on one hand, and 'matters of fact' on the other (Latour 2004).

\footnotetext{
${ }^{8}$ As I have discussed elsewhere, government attempts to remove swiftlet farms from George Town were made largely to protect the UNESCO World Heritage Status, which was seen to be threatened by the swiftlet farms (see Connolly, forthcoming; Connolly, 2016).
} 


\section{Conclusion}

This article has engaged with the literature on political ecology of health and disease to counterpose narratives regarding the potential health implications of swiftlet farming, as debated by various stakeholders. It focused on the case of George Town, Penang, to argue that narratives of health and disease continually police which landscape practices are acceptable for this increasingly globalizing and image-conscious city. Yet, given the lack of empirical evidence to prove or disprove the various claims that have been made, the government has not officially recognized the potential health risks posed by the swiftlet farming industry. This finding has strong implications concerning how 'legitimate knowledge' about health and disease is constructed and contested. For this reason, I argue that the political ecology of health literature can actually benefit rather than be limited by such contradictions and uncertainties, particularly when viewed through the lens of landscape political ecology.

The LPE approach utilized in this article is well suited for examining the political ecologies of health. As I have shown, the landscape concept can be utilized in seeing disease as not only determined through biophysical factors, but also constructed out of a particular set of social relations and lived experiences, which are mediated through the landscape. In this light, political economic factors, socio-ecological considerations, and health discourses constitute equally important factors in shaping health decision-making. In particular, they facilitate an understanding of how rhetorics of health and disease can be politically motivated and socially constructed. For instance, the case documented here has brought into view how narratives of health and disease have (in part) been used in establishing the urban(e) limits of George Town, and in determining appropriate relations between individuals and their urban environment. Moreover, I have emphasized the importance of examining how local knowledges - which are often grounded in embodied experiences - can conflict with official and 'elite' understandings or definitions of health and disease.

By digging into such controversies, I believe that this research can push forward Cook and Swyngedouw's recent call for urban research which can help to "stimulate a critical - and political - rethinking of the types of city-natures that we want to experience, now and in the future" (Cook and Swyngedouw 2012: 1975). In so doing, I have emphasized the need for critically evaluating the claims made by competing stakeholders to question how public space should be used, and by whom. After all, what is ultimately at stake in this case is who has the right to the city, which economic activities should be prioritized over others, and on what grounds.

\section{References}

Ali, S.H. and Keil, R. 2008. Networked disease: emerging infections in the global city, Malden, MA; Oxford: Wiley-Blackwell.

Anderson, J. 2004. Talking whilst walking: a geographical archaeology of knowledge. Area 36(3): 254-261.

Beardsworth, A.D. 1990. Trans-science and moral panics: understanding food scares. British Food Journal 92: 1-16.

Beck, U. 1992. Risk Society: Towards a new modernity. London: Sage.

Braun, B. 2008. Thinking the city through SARS: bodies, topologies, politics. In Ali, S.H. and Keil, R. (eds.). Networked disease: emerging infections in the global city. Oxford: Wiley-Blackwell. Pp. 250-266.

Brown, K.M. 2015. The role of landscape in regulating (ir)responsible conduct: moral geographies of the "proper control" of dogs. Landscape Research 40(1): 39-56.

Bunnell, T. 1999. Views from above and below: the Petronas twin towers and/in contesting visions of development in contemporary Malaysia. Singapore Journal of Tropical Geography 20(1): 1-21.

Chin, M.Y. 2009. Swift fortunes await. Starmag 23 Aug: SM4.

Chok, S.L. and H. Bhatt. 2006. In a fluff over bird's nest business. New Straits Times 13 July: 6.

Chuah, B.K. et al. 2010. Finding the swift way to earn megabucks. New Straits Times 29 March: 12.

Connolly, C. forthcoming. Whose landscape, whose heritage? The edible bird nest boom in George Town, Malaysia. Landscape Research. 
Connolly, C. 2016. A landscape political ecology of 'swiftlet farming' in Malaysian cities. PhD dissertation. Manchester: School of Environment, Education and Development, University of Manchester.

Cook, I. 2006. Geographies of food: following. Progress in Human Geography 30(5): 655-666.

Cook, I. and E. Swyngedouw. 2012. Cities, social cohesion and the environment: towards a future research agenda. Urban Studies 49: 1959-1980. draft

Cranbrook, L. 2010. An unfinished journey: some unresolved issues in Malaysian swiftlet research. Text to accompany a presentation made to the Malaysian Veterinary Department, 9 April 2010.

Cresswell, T. 1996. In place/out of place: geography, ideology, and transgression. Minneapolis: University of Minnesota Press.

de Certeau, M. 1984. The practice of everyday life. Berkeley: University of California Press.

Dickin, S.K., Schuster-Wallace, C.J. and Elliott, S.J. 2014. Mosquitoes and vulnerable spaces: mapping local knowledge of sites for dengue control in Seremban and Putrajaya Malaysia. Applied Geography 46: 71-79.

Douglas, M. 1970 (1966). Purity and danger: an analysis of concepts of pollution and taboo. London: Routledge.

Dunn, K. 2001. Representations of Islam in the politics of mosque development in Sydney. Tijdschrift voor Economische en Sociale Geografie 92(3): 291-308.

Freidberg, S. 2004. French beans and food scares culture and commerce in an anxious age. Oxford: Oxford University Press.

Gesler, W.M. 1992. Therapeutic landscapes: medical issues in light of the new cultural geography. Social Science and Medicine 34(7): 735-746.

Gesler, W.M. and R.A. Kearns. 2002. Culture/place/health. London: Routledge.

Henry, W. 2005. 10,000 swiftlet farms operating illegally? New Straits Times, 4 September: 4.

Ho, T.K., 2009. Swiftlet rearing in towns a health threat. The Star, 6 Feb: N49.

Hinchliffe, S. and Bingham, N. 2008. People, animals and biosecurity in and through cities. In Ali, S.H. and R. Keil (eds.). 2008. Networked disease: emerging infections in the global city. Oxford: WileyBlackwell. Pp. 214-228.

Keil, R. 2003. Urban political ecology. Urban Geography 24: 723-38.

King, B. 2010. Political ecologies of health. Progress in Human Geography 34(1): 38-55.

Kusenbach, M. 2003. Street phenomenology: the go-along as ethnographic research tool. Ethnography 4(3): 455-485.

Latour, B. 1987. Science in action: how to follow scientists and engineers through society. Cambridge, Mass.: Harvard University Press.

Latour, B. 2004. Why has critique run out of steam? From matters of fact to matters of concern. Critical Inquiry 30(2): 225-248.

Lee, E. 2010. No room for Swiftlets. The Star Online: 26 August (accessed 26.10.15).

Lim, C.K. and Cranbrook, G.G.-H. 2002. Swiftlets of Borneo: builders of edible nests. Kota Kinabalu: Natural History Publications (Borneo).

Lim, D., 2008. Report on the Malaysia Swiftlet Nest Industry Issues, Malaysia Bird's Nest House Owners Association (Accessed 29.3.15).

Loftus, A. 2012. Everyday environmentalism: creating an urban political ecology. Minneapolis: University of Minnesota Press.

Mangiameli, G. 2013. From mourning to environmentalism: a Sicilian controversy about children's deaths, political apathy and leukaemia. Journal of Political Ecology 20: 318-328.

Massey, D.B. 2005. For space. London: Sage.

Matless, D. 1998. Landscape and Englishness. London: Reaktion Books. 
May, J.M. 1954. Cultural aspects of tropical medicine. American Society of Tropical Medicine and Hygiene 3: 422-430.

Mayer, J.D. 1996. The political ecology of disease as one new focus for medical geography. Progress in Human Geography 20: 441-456.

McGee, T.G. 2002. Reconstructing "the Southeast Asian city" in an era of volatile globalization. In T. Bunnell, L.B.W. Drummond and K.C. Ho (eds.). Critical reflections on cities in Southeast Asia. Singapore: Times Academic Press. Pp. 31-53.

Merican, E.H.S. 2007. The 2007 Malaysian Swiftlet farming industry report (Summary and Synopsis). SMI Association of Penang.

Moore, S., 2006. Forgotten roots of the green city: subsistence gardening in Columbus, Ohio, 1900-1940. Urban Geography 27(2): 174-192.

Muhammad, Z. 2007. Birds a living hell for residents. New Straits Times 14 February.

Mulligan, K., S.J. Elliott and C. Schuster-Wallace, 2012. The place of health and the health of place: Dengue fever and urban governance in Putrajaya, Malaysia. Health \& Place 18(3): 613-620.

Nash, L.L. 2006. Inescapable ecologies: a history of environment, disease, and knowledge. Berkeley: University of California Press.

Nathan, S. 2003. "More Seminars" plan for bird's nest farmers. The Star 6 June: 13.

Nation, The, 2013. H5N1 virus hits birds-nest farm in Vietnam. (accessed 1.6.14).

Neumann, R.P. 2011. Political ecology III: theorizing landscape. Progress in Human Geography 35(6):843850.

New Straits Times, 2009. No need to worry about bird flu. 11 Sep. Print.

New Straits Times, 2009. A health hazard not many are aware of. 9 Sep. Print.

NSHiGT (No Swiftlet Houses In George 2010. http://noswiftlethousesingeorgetown.blogspot.com/feeds/posts/default (accessed 9.12.2013).

Notzke, C. 2013. An exploration into political ecology and nonhuman agency: the case of the wild horse in western Canada. The Canadian Geographer/Le Géographe Canadien 57(4): 389-412.

Oh, K.S. 2009. Just taking wing but it's an honest trade. The Star 10 Feb: np.

Parizeau, K. 2015. Urban political ecologies of informal recyclers' health in Buenos Aires, Argentina. Health \& Place 33: 67-74.

Philo, C. 1995. Animals, geography and the city: notes on inclusions and exclusions. Environment and Planning D: Society and Space. 13: 655-681.

Peterson, K. 2009. Phantom epistemologies. In Faubion J.D and G.E. Marcus (eds.) Fieldwork is not what it used to be: learning anthropology's method in a time of transition. Ithaca, NY: Cornell University Press. Pp. 37-51.

PLGCF (Penang Local Government Consultative Forum), 2010. Minutes of Meeting, Dewan Bosch, Kompleks Masyarakat Penyayang.

Proctor, J. 1998. The Spotted Owl and the contested moral landscape of the Pacific Northwest. In Wolch, J. and Emel, J. (eds.) Animal geographies: place, politics, and identity in the nature-culture borderlands. London: Verso. Pp. 191-217.

Schein, R. 1997. The place of landscape: a conceptual framework for interpreting an American scene. Annals of the Association of American Geographers 87(4): 660-680.

See, E., 2004. Rearing of swiftlets a potential health hazard. The Star 6 Feb: np.

Setten, G. and K.M. Brown 2009. Moral landscapes. In R. Kitchin and N. Thrift (eds.). The international encyclopedia of human geography (Vol. 7). Oxford: Elsevier. Pp. 191-195.

Shankar, A. 2014. Dengue on the rise in Penang. Free Malaysia Today (accessed 26.3.14)

Star, The, 2005. Chang: no need to play music all day long. 3 Aug. Print. 
Swyngedouw, E. 2006. Circulations and metabolisms: (hybrid) natures and (cborg) cities. Science as Culture 15(2): 105-121.

Tan, Y.S. 2007. Not in towns please. New Straits Times 10 December: 29.

Thomson, M. 2007. Placing the wild in the city: "thinking with" Melbourne's bats. Society and Animals 15: 79-95.

Thorburn, C. 2014. The edible birds' nest boom in Indonesia and South-east Asia: a nested political ecology. Food, Culture and Society: An International Journal of Multidisciplinary Research 17: 535-553.

Tsing, A. L. 2005. Friction: an ethnography of global connection. Princeton, N.J: Princeton University Press.

Walker, P. and L. Fortmann. 2003. Whose landscape? A political ecology of the exurban Sierra. Cultural Geographies 10: 469-491. 